\title{
Comparative Biometrics of a Teleost Fish, Boops boops (Lin- naeus, 1758) (Perciformes Sparidae) of the Algerian coast lines
}

\author{
Boubaiou Abla', Ali Tahar' \& Lyamine Mezedjri $i^{*}$ \\ ${ }^{1}$ Department of Biology, Faculty of Sciences, Badji Mokhtar University, 23000 Annaba, Algeria; e-mail: abla1_bio@yahoo.fr \\ ${ }^{2}$ Department of Natural Sciences and Life, Faculty of Sciences, University August 20, 195521000 Skikda, Algeria; e-mail: \\ mezedjri.lyamine@gmail.com. \\ *Corresponding author
}

ABSTRACT

Algeria is a country characterized by its diversified ichthyological fauna of economic and ecological importance, which deserves to be valorized by a scientific study. Due to this, our study is dedicated to the comparative biometry of the Boops boops (Linnaeus, 1758) (Perciformes Sparidae), between seven sites located on the Algerian coastline from north-east to north-west: El-kalla, Annaba, Skikda, Collo, Jijel, Algiers, Mostaganem. This study is made due to the total absence of reliable and exploitable information concerning the morphometric and meristic characteristics of this Algerian coast fish. The comparative study was carried out using thirty-six morphometric and meristic variables. The analytical approach carried out shows that environment factors have an influence and effect, not only on the diversity of living beings, but on the morphological variation in the same species. In addition, the statistical approach allowed a spatiotemporal evaluation of the biometry of the B. boops from the seven sites. As a first step, all the univariate statistical analyzes carried out, suggest significant differences between the seven sites, as well as a possible sexual dimorphism. Also, the analysis of variance at a fixed model classification criterion shows, with respect to the site factor, very significant to very highly significant differences between the seven sites for thirty variables out of thirty-six; for the sex factor, there are no significant differences for thirty-two variables out of thirty-six. Other models have been studied. Thus, in general, the general linear model MANOVA confirms the results obtained by the ANOVA.

\section{INTRODUCTION}

The biology or morphology of Boops boops (Linnaeus, 1758) (Perciformes Sparidae) has been studied in many areas: Tunisian coasts (Anato \& Ktari, 1986), Moroccan (Zoubi, 2001a, b; Zoubi et al., 2004), Spanish (Zuniga, 1967), northwestern
Mediterranean (Trangridis \& Filippouzis, 1991; Sanchez-Velasco \& Norbis, 1997), and Greece (Karpouzi et al., 2000). In Algeria, the study of the biology of the fish is limited in some works we quote that were carried out on the coasts of Bou-Ismail (Chali-Chabane, 1988) and Béni-Saf (Djabali et al., 1991). On the coast of Skikda, data on the bi- 
ology or biometry of the $B$. boops fish and its ecology are missing.

As a result, our study attempts to answer a need for information on the B. boops biometrics of the Algerian coast, by comparing its biometric parameters of the samples taken from seven sites located on the Algerian coastline from East to West: ElKalla, Annaba, Skikda, Collo, Jijel, Algiers, and Mostaganem. The biometric study is based on statistical processing of morphometric and meristic variable data measured on samples of the fish.

\section{MATERIAL AND METHODS}

The biometric study is based on samples of the $B$. boops fish taken from seven sites located along the Algerian coastline from north-east to northwest: El-kalla, Annaba, Skikda, Collo, Jijel, Alger, and Mostaganem.

A sample of 30 individuals (from 2.5 to $4 \mathrm{~kg}$ ) is taken into consideration in each site, respecting as much as possible all size classes present. The details are given in Table 1. Each individual is wrapped in plastic film immediately after collection to avoid damage, and is put in the freezer at $-20{ }^{\circ} \mathrm{C}$. In the laboratory, a series of 36 morphometric and meristic measurements are made on each fish (Fig. 1).

Any statistical study can be broken down into at least two phases: the collection or collection of data, on one hand, and their analysis or interpretation, on the other.

Data collection has been dealt with in the previous paragraph. As for statistical analysis, it can be broken down into two stages, one deductive or descriptive and the other inductive.

The purpose of descriptive statistics is to measure and present the observed data in such a way that it can easily be seen, for example in the form of tables or graphs.

Statistical inference makes it possible to study or generalize under certain conditions the conclusions thus obtained by means of statistical tests by taking certain risks of error which are measured using the theory of probabilities.

For our work, all the calculations were performed for each variable and for each of the 7 sites, using a DELL-type microcomputer and using the Minitab version 16.1 statistical analysis and statistical processing software (X, 2011).

\section{Univariate statistical analyzes}

Description of the data. To better describe the different characteristics obtained by site, we calculated some basic statistical parameters such as the arithmetic mean (x), which is a parameter of central position and trend, the standard deviation (s), which measures the dispersion of the data around the mean, the minimum $\left(\mathrm{x}_{\min }\right)$ and maximum $\left(\mathrm{x}_{\max }\right)$ values which both give an idea of the extent of the data, and finally the size (n) which informs us about the importance of the data processed.

Cross-site comparison of average characteristics: Variance analysis test. To compare the averages for each of the 36 characteristics among the seven sites, we used the one-way variance analysis test or the fixed model classification factor. This test consists in comparing the averages of several populations from random, simple, and independent sample data (Dagnelie, 1970, 2006).

The test is performed either by comparing the value of $\mathrm{F}_{\mathrm{obs}}$ with the corresponding theoretical value $\mathrm{F}_{(1-\alpha)}$, extracted from the Fisher's F-table for a significance level $\alpha=0.05$ or 0.01 or 0.001 and for $\mathrm{k} 1$ and $\mathrm{k} 2$ degrees of freedom, either by comparing the value of the probability $p$ with always the

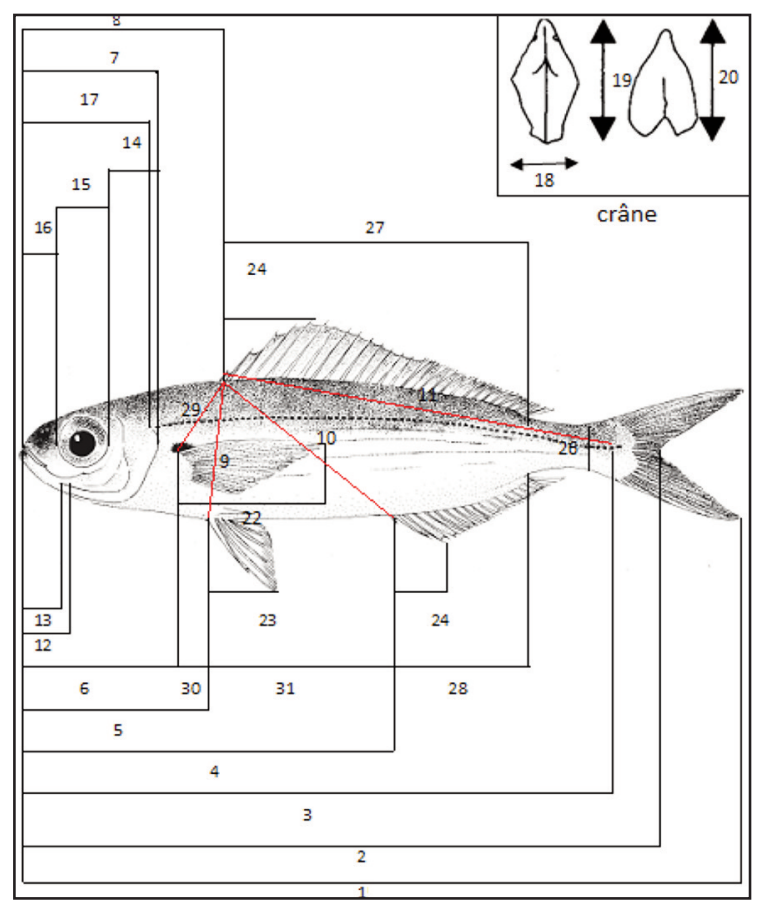

Fig.1 : Morphometric measurements made on each fish. 
different values of $(\alpha)$, for values $\alpha=0.05$ or $\alpha=$ 0.01 or $\alpha=0.001$ (Mezedjri \& Tahar 2007; 2008a, 2008b).

Depending on whether this hypothesis of equality of means is rejected at the level $\alpha=0.05,0.01$ or 0.001 , it is conventionally said that the difference observed between the means is significant, highly significant or very highly significant. These differences of one, two or three asterisks are generally marked (Dagnelie, 1970, 2006).

This test was used to compare, on one hand, between the seven sites, the averages of each of the 36 variables and, on the other hand, to compare between the two sexes in each site, the averages of the 36 presumed variables (Mezedjri \& Tahar, 2008a, b).

Calculations are made using the Minitab software GLM procedure $(X, 2011)$ for each of the 36 variables at the 7 sites.

\section{Multivariate statistical analyzes}

Comparison between sites for all characteristics: multivariate MANOVA variance analysis test. The comparison between the 7 sites for all 36 variables studied and between the two sexes in the 7 sites for all the variables measured, was performed by using multivariate analyses of variance using three statistical tests, that are: Wilk's lambda, Lawley-Hotteling, and Pillai's trace (Dagnelie, 1970, 1986, 2006).

This method is an extension of the univariate variance analysis, in which we have several variables that were observed simultaneously on the same individuals (or sites). The three tests cited above and proposed by Palm (2000) and Dagnelie $(1970,2006)$ are all asymptotically equal in power, and no test can be recommended in a systematic way, preferably to others (Dagnelie, 1986). According to Huberty (1994), the Wilk's test is the most popular.

\section{RESULTS AND DISCUSSION}

\section{Results of univariate statistical analyzes}

Calculation of basic statistical parameters. To better describe the different variables that characterize the individuals studied in two different sites,

\begin{tabular}{|c|c|c|}
\hline \multicolumn{3}{|c|}{ Morphometric variables } \\
\hline Number & Code & Description \\
\hline 1 & $\mathrm{Lt}$ & Total length \\
\hline 2 & Lf & Fork length \\
\hline 3 & Ls & Standard length \\
\hline 4 & Lpan & Pre-anal length \\
\hline 5 & Lppv & Pre-pelvic length \\
\hline 6 & Lppc & Pre-chest length \\
\hline 7 & Lcep & Cephalic length \\
\hline 8 & Lpdo & Pre-dorsal length \\
\hline 9 & Dopv & Dorsal / pelvic distance \\
\hline 10 & Doan & Dorsal / anal distance \\
\hline 11 & Doca & Dorsal / caudal distance \\
\hline 12 & Lman & Length of the mandible \\
\hline 13 & Lmax & Maxillary length \\
\hline 14 & Poor & Distance poste orbitaire \\
\hline 15 & Dor & Orbital position distance \\
\hline 16 & Pror & Pre-orbital distance \\
\hline 17 & Lpop & Preoperative length \\
\hline 18 & Lain & Inorbital width \\
\hline 19 & Lcra & Skull length \\
\hline 20 & Mist & Mandible / Isthmus length \\
\hline 21 & Lapc & Distance between pectoral insertions \\
\hline 22 & $\mathrm{Hpc}$ & Height of the pectoral \\
\hline 23 & Hpv & Height of the pelvic \\
\hline 24 & Hdo & Height of the dorsal \\
\hline 25 & Han & Anal height \\
\hline 26 & Hpdc & Height of the peduncle \\
\hline 27 & Bado & Base of the dorsal \\
\hline 28 & Baan & Base of the anal \\
\hline 29 & Dopc & Dorsal / pectoral distance \\
\hline 30 & Pcpv & Pectoral / pelvic distance \\
\hline 31 & Pvan & Pelvic / anal distance \\
\hline 32 & Cæc & Number of pyloric caecum \\
\hline 33 & Brin & $\begin{array}{l}\text { Number of lower gill rakers of the } \\
\text { 1st left branchial arch }\end{array}$ \\
\hline 34 & Brsu & $\begin{array}{l}\text { Number of upper gill rakers of the } \\
\text { lst left branchial arch }\end{array}$ \\
\hline 35 & Ryp & Number of rays of the left chest \\
\hline 36 & Ryp & Number of left pelvic rays \\
\hline
\end{tabular}

Table 1. Morphometric and meristic variables studied.

\begin{tabular}{|l|lll|lll|}
\hline \multicolumn{1}{|c|}{ Sites } & \multicolumn{4}{c|}{ Males } & \multicolumn{3}{c|}{ Females } \\
\cline { 2 - 7 } & n & Lt min & Lt max & n & Lt min & Lt max \\
\hline El-kala & 33 & 13.20 & 18.20 & 5 & 14.60 & 16.60 \\
Annaba & 16 & 15.30 & 24.70 & 10 & 14.60 & 24.50 \\
Skikda & 26 & 17.20 & 22.70 & 15 & 15.70 & 21.50 \\
Collo & 30 & 14.00 & 21.00 & 4 & 15.80 & 19.00 \\
Jijel & 19 & 13.80 & 21.30 & 21 & 14.40 & 22.00 \\
Alger & 17 & 14.80 & 21.30 & 21 & 14.50 & 21.90 \\
Mostaganem & 13 & 13.70 & 17.80 & 30 & 14.80 & 19.00 \\
\hline
\end{tabular}

Table 2. Description of the data for each site. 
we calculated some basic statistical parameters such as the arithmetic mean (x) which is a parameter of central position and trend, the difference type (s), that measures the dispersion of the data around the mean $(\mathrm{x})$, the minimum values $\left(\mathrm{Lt}_{\mathrm{min}}\right)$ and maximum values $\left(\mathrm{Lt}_{\mathrm{max}}\right)$, which both give an idea of the extent of the data, and finally inform us about the size and the importance of the collected samples.

The biometric study was conducted using $B$. boops samples taken from seven different sites on the Algerian coast. We have inventoried a total of 261 individuals including 154 males, of which their total length Lt varies between $24.70 \mathrm{~cm}$ and 13.20 $\mathrm{cm}, 106$ females, of which their $\mathrm{Lt}$ varies between $24.50 \mathrm{~cm}$ and $14.40 \mathrm{~cm}$, and only two fish of indeterminate sex (Table 2).

It is noted that the total length Lt of the males is greater than that of the females for the sites of the gulf of El-kalla, Annaba, Skikda, and Collo whereas for the sites of the gulf, Jijel, Mostaganem, and the bay of Algiers it is reversed.

\section{MANOVA multivariate analysis of variance}

The analysis of variance has several variables or dispersion analysis, essentially to compare the averages of more than two populations for several variables (Dagnelie, 2000).

This is an extension of the univariate variance analysis, in which we have several variables that were observed simultaneously on the same individuals. Dagnelie (2000) and Palm (2000) provide several tests to perform the multivariate analysis of variance which are: the Wilk's Lambda test, Pillai's Trace, and Lawley-Hotelling. However, all these tests are asymptotically equal in power, and no test can be recommended in a systematic way, in preference to others (Dagnelie, 2000). According to Huberty (1994), the Wilk's test is the most popular.

The Minitab MANOVA command applied to the data of the two sites to perform multivariate variance analysis has two fixed classification criteria and whose sex factor is hierarchical at the site factor gives the results of the two following Tables 4, 5 .

\section{CONCLUSIONS}

The aim of this work was to study the biometry of the $B$. boops taken from seven sites located along

\begin{tabular}{|c|c|c|c|c|}
\hline & \multicolumn{2}{|c|}{ Factor site } & \multicolumn{2}{|c|}{ Factor sexe } \\
\hline Variables & Fobs & $\mathbf{P}$ & Fobs & $\mathbf{P}$ \\
\hline Lt & 15.33 & $0.000 * * *$ & 1.92 & $0.067 \mathrm{~ns}$ \\
\hline Lf & 12.40 & $0.000 * * *$ & 1.63 & $0.128 \mathrm{~ns}$ \\
\hline Ls & 14.24 & $0.000 * * *$ & 2.17 & $0.038 *$ \\
\hline Lpan & 12.11 & $0.000 * * *$ & 1.85 & $0.079 \mathrm{~ns}$ \\
\hline Lppv & 12.49 & $0.000 * * *$ & 1.10 & $0.366 \mathrm{~ns}$ \\
\hline Lppc & 13.31 & $0.000 * * *$ & 0.58 & $0.772 \mathrm{~ns}$ \\
\hline Lcep & 9.02 & $0.000 * * *$ & 1.48 & $0.174 \mathrm{~ns}$ \\
\hline Lpdo & 11.34 & $0.000 * * *$ & 1.28 & $0.259 \mathrm{~ns}$ \\
\hline Dopv & 3.77 & $0.001 * * *$ & 1.04 & $0.407 \mathrm{~ns}$ \\
\hline Doan & 7.21 & $0.000 * * *$ & 1.47 & $0.177 \mathrm{~ns}$ \\
\hline Doca & 7.42 & $0.000 * * *$ & 2.01 & $0.054 \mathrm{~ns}$ \\
\hline Lman & 1.90 & $0.081 \mathrm{~ns}$ & 1.12 & $0.350 \mathrm{~ns}$ \\
\hline Lmax & 5.93 & $0.000 * * *$ & 0.36 & $0.926 \mathrm{~ns}$ \\
\hline Poor & 9.19 & $0.000 * * *$ & 1.36 & $0.221 \mathrm{~ns}$ \\
\hline Dor & 0.35 & $0.910 \mathrm{~ns}$ & 0.54 & $0.807 \mathrm{~ns}$ \\
\hline Pror & 8.57 & $0.000 * * *$ & 0.49 & $0.839 \mathrm{~ns}$ \\
\hline Lpop & 11.91 & $0.000 * * *$ & 0.74 & $0.640 \mathrm{~ns}$ \\
\hline Lain & 3.33 & $0.004 * *$ & 0.42 & $0.887 \mathrm{~ns}$ \\
\hline Lera & 18.23 & $0.000 * * *$ & 0.52 & $0.818 \mathrm{~ns}$ \\
\hline Mist & 9.48 & $0.000 * * *$ & 6.97 & $0.000 * *$ \\
\hline Lapc & 7.17 & $0.000 * * *$ & 1.11 & $0.356 \mathrm{~ns}$ \\
\hline Нрс & 14.77 & $0.000 * * *$ & 0.81 & $0.580 \mathrm{~ns}$ \\
\hline Hpv & 7.98 & $0.000 * * *$ & 0.96 & $0.461 \mathrm{~ns}$ \\
\hline Hdo & 3.60 & $0.002 * *$ & 1.01 & $0.426 \mathrm{~ns}$ \\
\hline Han & 3.13 & $0.006 * *$ & 2.22 & $0.033 *$ \\
\hline Hpdc & 3.94 & $0.001 * * *$ & 0.44 & $0.873 \mathrm{~ns}$ \\
\hline Bado & 11.61 & $0.000 * * *$ & 1.35 & $0.226 \mathrm{~ns}$ \\
\hline Baan & 16.33 & $0.000 * * *$ & 1.64 & $0.124 \mathrm{~ns}$ \\
\hline Dopc & 9.34 & $0.000 * * *$ & 0.62 & $0.736 \mathrm{~ns}$ \\
\hline Pcpv & 10.48 & $0.000 * * *$ & 1.98 & $0.059 \mathrm{~ns}$ \\
\hline pvan & 7.26 & $0.000 * * *$ & 2.05 & $0.050 *$ \\
\hline Cæc & 23.37 & $0.000 * * *$ & 0.29 & $0.958 \mathrm{~ns}$ \\
\hline Brin & 12.79 & $0.000 * * *$ & 0.48 & $0.851 \mathrm{~ns}$ \\
\hline Brsu & 3.98 & $0.001 * * *$ & 0.67 & $0.701 \mathrm{~ns}$ \\
\hline Rypc & 16.11 & $0.000 * * *$ & 0.85 & $0.544 \mathrm{~ns}$ \\
\hline Rypv & 2.96 & $0.008 * *$ & 1.30 & $0.249 \mathrm{~ns}$ \\
\hline \\
\hline
\end{tabular}

Table 3. Results of the analysis of variance at a fixed model classification criterion of the comparison, between sites and sexes (sites), of the means of each of the 36 variables. 


\begin{tabular}{|c|c|c|c|c|}
\hline Tests & $\begin{array}{c}\text { Observed } \\
\text { value of } \\
\text { the test }\end{array}$ & Fobs & DL & $P$ \\
\hline \begin{tabular}{|l|} 
Wilks' \\
\end{tabular} & 0.02235 & 5.191 & $216 ; 1247$ & $0.000 * * *$ \\
\hline $\begin{array}{l}\text { Lawley- } \\
\text { Hotelling }\end{array}$ & 5.94605 & 5.707 & $216 ; 1244$ & $0.000 * * *$ \\
\hline Pillai's & 2.64014 & 4.671 & $216 ; 1284$ & $0.000 * * *$ \\
\hline
\end{tabular}

Table 4. MANOVA for Sites. Multivariate tests used to test the equality of mean vectors between sites.

\begin{tabular}{|l|c|c|c|c|}
\hline \multicolumn{1}{|c|}{ Tests } & $\begin{array}{c}\text { Observed } \\
\text { value of } \\
\text { the test }\end{array}$ & Fobs & DL & P \\
\hline $\begin{array}{l}\text { Wilks' } \\
\text { Lawley- } \\
\text { Hotelling }\end{array}$ & 0.28418 & 1.155 & $252 ; 1451$ & $0.062 \mathrm{~ns}$ \\
Pillai's & 1.130953 & 1.159 & $252 ; 1451$ & $0.057 \mathrm{~ns}$ \\
\hline $\mathrm{p}>\alpha=0,05$ : (ns) differences not significant & 1.150 & $252 ; 1505$ & $0.067 \mathrm{~ns}$ \\
\hline
\end{tabular}

Table 5. MANOVA for Sexes (Sites). Multivariate tests used to test the equality of mean vectors between the two sexes in the sites.

the Algerian coastline from north-east to northwest: El-kalla, Annaba, Skikda, Collo, Jijel, Alger, Mostaganem.

The comparative biometric study between the seven sites showed that the application of the generalized linear model or the analysis of the variance to a criterion of ANOVA fixed model classification carried out for each of the 36 variables measured to compare between the seven sites and between the two sexes, showed that:

- Regarding the site factor, we find that there are highly to very highly significant differences for 34 out of 36 variables. The 4 variables where the differences are highly significant are: Rypv, Lain, Hdo, and Han, the 2 variables that do not show significant differences are: Dor and Lman.

- For the sex factor, there are no significant differences for 32 out of 36 variables. Variables with significant differences at the $\alpha=5 \%$ level are: Ls, Han, and Pvan. The Mist variable (mandible-isthmus) has very highly significant differences at the $\alpha=0.1 \%$ level.

\section{ACKNOWLEDGEMENTS}

At the end of this work, I feel both the joy and the duty of thanking all those who have helped me in the development of this study, and those who have contributed in one way or another to my scientific training.

\section{REFERENCES}

Anato C.B. \& Ktari M.H., 1986. Age and growth of Boops boops L. of the tunisian coast. Bulletin de l'Institut National Scientifique et Technique d'Océanographie et de Pêche de Salammbô, 13: 3354.

Chalabi-Chabane F., 1988. Contribution à l'étude biologique et dynamique de la bogue, Boops boops (Linnaeus, 1758) de la baie de Bou-Ismail. Thèse de magistère Institut des sciences de la mer et de l'aménagement du littoral, Algérie, $111 \mathrm{pp}$.

Dagnélie P., 1970. Théorie et méthodes statistiques: applications agronomiques (vol. 2). Gembloux, Presses agronomiques, $451 \mathrm{pp}$.

Dagnélie P., 1986. Analyse statistique à plusieurs variables. Gembloux, Presses agronomiques, $362 \mathrm{pp}$.

Dagnélie P., 2006. Statistique théorique et appliquée. Tomme 2: Inférences à une et à deux dimensions. Bruxelles-université De Boeck et Larcier, 659 pp.

Djabali F., Brahim B. \& Mamas S., 1991. Empirical equations for the estimation of natural mortality in Mediterranean teleosts. Naga. ICLARM, Q. 16: 35-37.

Huberty C.J., 1994. Applied discriminate analysis. New York, Wiley, 466 pp.

Karpouzi V.S., Stergion K.I. \& Moutopoulos D.K., 2001. Relationships between maximum girth and body length for several marine fishes. Aristotle University, Scool of Biology. Departement of Zoology, Thessaloniki, Greece. Bulletin de la Commission Internationale pour 1'Exploration Scientifique de la mer Méditerranée, 36: 1-285.

Mezedjri L. \& Tahar A., 2007. Morphological variability, between two sites in Mediterranean population of the European anchovy: Engraulis encrasicolus. Journal of Fisheries International, 2: 65-68. DOI: jfish.2007. 65.68

Mezedjri L. \& Tahar A., 2008a. Détermination d'un dimorphisme sexuel chez deux populations d'Engraulis encrasicolus (Linné, 1758) en utilisant la statistique descriptive univariée. Actes du Workshop International sur la gestion des ressources halieutiques GRH 2007. Numéro spécial décembre 2008. Revue semestrielle des sciences de la mer, Pélagos, ISMAL, 106-112. 
Mezedjri L. \& Tahar A., 2008b. Influence des facteurs environnementaux sur la variabilité morphologique de l'anchois Européen Engraulis encrasicolus (Linné, 1758) entre le golfe de Skikda (Algérie) et le golfe du Lion (France). Actes du Workshop International sur la gestion des ressources halieutiques GRH 2007. Numéro spécial décembre 2008. Revue semestrielle des sciences de la mer, Pélagos, ISMAL, 137-144.

Minitab 16 Statistical Software, 2011. [Computer software]. State College, PA: Minitab, Inc. (www.minitab.com).

Palm R., 2000. L'analyse de la variance multivariée et l'analyse canonique discriminante: principes et applications. Notes de statistique et d'informatique 2000/1, Gembloux, 40 pp.

Sanchez-Velasco L. \& Norbis W., 1997. Comparative diets and feeding habitats of Boops boops and Diplodus sargus larvae, two sparid fishes co-occuring in the northwestern Mediterranaen. Bulletin of Marine Science, 61: 821-835.

Trangridis A. \& Filippouzis N., 1991. Use of lengthfrenquency data in the estimation of growth parame- ters of three Mediterranean fish species: bogue (Boops boops L.), picarel (Spicara smaris L.) and horse markere (Trachurus trachurus L.). Fisheries Research, 12: 283-297.

Zoubi A., 2001a. Étude de la biologie de croissance des principaux stocks démeseaux de la Méditerranée Marocaine. Institut National de Recherche Halieutique (INRH), Casablanca, Maroc, Rapport commission international mer Méditerranée, 36: 341 pp.

Zoubi A., 2001b. Biologie de la reproduction des principaux espèces démersales de la Méditerranée Marocaine. Institut National de Recherche Halieutique (INRH), Casablanca, Maroc, Rapport commission international mer Méditerranée, 36: 340 pp.

Zoubi A., Berraho A. \& Shafee M.S., 2004. Étude des possibilités d'aménagement des Sparidés dans la région méditerranéenne Marocaine. Rapport commission international mer Méditerranée, 37: 465 pp.

Zuniga L.R., 1967. Estudio del Creciniento de la boga en el Levante Espagnole. Investigacion Pesquera, 31: 383-418. 